\title{
An Investigation of Inaction in Samuel Beckett's Waiting for Godot: A Literary Darwinian Perspective
}

\author{
Bahareh Merhabi ${ }^{1} \&$ Amrollah Abjadian² \\ ${ }^{1} \mathrm{PhD}$ Candidate in English Literature, Shiraz University, Iran. \\ Email: Baharmehrabi22@gmail.com. \\ ${ }^{2}$ Amrollah Abjadian is Professor, English Literature Shiraz University, Shiraz, Iran.
}

Received May 25, 2016; Revised July 21, 2016; Accepted July 30, 2016; Published August 18, 2016

\begin{abstract}
The aim of this paper is to develop a literary Darwinian reading of Samuel Beckett's Waiting for Godot. The attributes of human nature defined by Joseph Carroll are discussed with regard to characters' inaction. Waiting for Godot stages the unstable and uncertain status of modern man, suffering lack of communication. Constructive elements of human nature such as the acts towards survival, romance and nurture are discussed in order to delineate the inactive pattern of characters' behaviors in Waiting for Godot. It becomes clear that lack of action in Vladimir and Estragon pinpoints the fall and paralysis of human nature as defined by the literary Darwinists. This article demonstrates that, as a result of uncertainty, anxiety and other disastrous consequences of the Second World War, the attributes of human nature, along with the agency as the power for committed action, as defined by the Literary Darwinists, are forgotten, paralyzed or ignored. Man is staged as a creature incapable of agency that is reduced to inaction because of the post-war catastrophic situation.
\end{abstract}

Keywords: Waiting for Godot, Literary Darwinism, Joseph Carroll, Human Nature, Inaction.

Samuel Beckett's Waiting for Godot yields to a number of different approaches for reading between the lines. This paper presents a literary Darwinian perspective to Beckett's famous play. Darwinism in Literature demonstrates strong affiliations with other disciplines such as evolutionary and folk psychology and its main assumptions basically emerge from the Darwinian thought in social sciences in general. Literary Darwinists are concerned with the universal sets of behavioral patterns that are common to human species. Joseph Carroll is the literary Darwinist whose classifications of the universal human nature attributes, defined more specifically in Reading Human Nature are considered as the main theoretical framework in this article for the investigation of inaction in the main characters of Waiting for Godot

Modern man and his life philosophy are inseparable elements of Beckett's dramaturgy. He is deeply concerned with the ennui and depression that has penetrated into man's mode and actions in the modern era. As Carrabino (1985) states; it is true and universally agreed upon that modern man is suffering sadness, ennui and void which are experienced in the modern era (p.66). The core issues staged in Waiting for Godot vary from the tramps suffering to their attempts to pass time and to their taking part in an endless process of inaction and waiting for Godot. Waiting

(c) AesthetixMS 2016. This Open Access article is published under a Creative Commons Attribution Non-Commercial 4.0 International License (http://creativecommons.org/licenses/by-nc/4.o/), which permits non-commercial re-use, distribution, and reproduction in any medium, provided the original work is properly cited. For citation use the DOI. For commercial re-use, please contact editor@rupkatha.com. 
and inaction are two important concepts presented in Samuel Beckett's. To Sartre, Waiting for Godot is a drama in which "nothing really happens" (qtd in Cohn, 1967, p.106). Lois Gordon (2002) argues that "Vladimir and Estragon share the singularly most profound life goal; that is, of determining a purpose for living, is clear in the very name of their quest: Godot" (55). The obvious inaction and lack of power or agency to accomplish goals is observable through the play. Although Beckett's characters may lose the capacity for action, the dominant feeling of inaction is what they are all aware of. They do desire to act, but they cannot do anything about it. It is possible to agree that "Their awareness of their own self continues relentlessly; and time can never have a stop" (Esslin, 1965, p.7). Themes of waiting and inaction are thus commonly regarded as core issues in Waiting for Godot; however, these can be regarded from a Darwinian approach as failures on the parts of characters to survive.

In this article, the motif of action or inaction, is investigated with regard to the features of Darwinist view of human nature with emphasis on survival, finding or keeping spouse, gaining or keeping power and wealth, binding with friends, gaining culture and education and building or making something new, in order to see whether the characters in Waiting for Godot prove to demonstrate the necessary agency to accomplish life goals or not. The attributes of human nature attributes defined in Literary Darwinism can be traced back in Beckett's play to delineate how the absence of agency and willingness to act leads to staging the fall and paralysis of human nature.

Drama as a "mirror held up to nature" provides the best macrocosm for this trend, but Beckett's Waiting for Godot stages the absence of proper attributes of human nature in the modern man living in the catastrophic trauma of the time. The main argument of the article is that action is paralyzed in the play. Borrowing from the definition of the attributes of universal human nature provided by Joseph Carroll in his recently published book Reading Human Nature, inaction in Waiting for Godot is brought under scrutiny. The article is organized by an overall description of the Darwinian literary criticism, followed by the application of Carroll's major categories of the attributes of human nature to the events and characters of Waiting for Godot.

\section{Discussion}

\section{Literary Darwinism: Joseph Carroll}

Darwinism in literature emerged from the core concepts of evolutionary psychology and the way human behavior is described in light of its biological origins in the language of survival, reproduction and the propagation of genes. Wilson (1978) believes that the core argument is that "the brain exists because it promotes the survival and multiplication of the genes that direct its assembly. The human mind is a device for survival and reproduction" (p.2). The core principle is that human psychology- the mind- is the product of evolution by natural selection. Therefore, humans are claimed to act on the bases of, not only their belief and desire, but also under the circumstance to proliferate their genes. From this point of view, literature is, as one manifestation of human behavior, a form of adapted faculty. Evolutionary psychology can thus show us why we read works of literature and how reading literature is as much a part of our biology.

Literary theorists who would call themselves "literary Darwinists" or claim some close alignment with them, share one central idea: that the adapted mind produces literature and that literature reflects the structure and character of the adapted mind. Recently, some critics and philosophers such as Franco Moretti, Joseph Carroll, and Daniel Dennet have each presented important models for the application of Darwinism to literary study Carroll (2011) defines human 
nature as the expression of the fact that all humans are common owners of some species-typical dispositions, "basic motives tied closely to the needs of survival, mating, parenting, and social interaction" (p.27). Arts, in general, and literature in particular are the outward expressions of different ways these dispositions have been shaped by the surrounding culture. He has generalized the features in human nature and explain motives as "the chief organizing principle in human behavior". The features can fall into four major categories: constructive effort, romance, nurture, and subsistence (159).

The behavioral patterns of humanity could be traced back as a set of normal and homogenous motives and expressions which eventually shape the "life-history" of human species. The core concept in this pattern concerns the attributes of social groupings as man is essentially a social being. The sets of motives, described by Carroll, which serve as the primary framework for the present study, have one thing in common: they are all essentially related to movement and action. That is, if the character is to be regarded as a protagonist, he or she might demonstrate the positive progress in line with these motives and attempt to enforce those motives in the course of his or her actions. Agency or the power to accomplish those goals, therefore, plays an important role. "The success or failure of the character in achieving his or her goals is the main action in the story, broadly the 'plot'. Goals are the end-objects of motives for instance, the desire to survive, to get married, to make friends, to obtain education, or to assist one's friends" (Carroll, 2004, p.217).

Carroll believes that every human being, no matter where or when he lives, shares these motives and demonstrates these attributes in the course of his/her life. "Constructive effort most strongly characterizes protagonists, both male and female. It consists of two pro-social elements (helping non-kin and making friends) and two cultural elements (seeking education and building or creating something)". (Carroll, 2011, 159) It is further discussed that male protagonists are motivated "by subsistence that is, by survival and by doing routine work to earn a living". In addition to these two categories and the motives which are included in their sub-categories, "mating efforts" are also the third group of human nature attributes which consist of "Romance and Nurture (caring for offspring and other kin)" (Carroll, 2011, 159). Carroll's ideas are developed further in the following sections so as to investigate the inaction of the characters in Waiting for Godot in details.

\section{Action as a Mode of Survival in Waiting for Godot}

Act toward survival, Carroll states, is the one which leads to a safer life and includes any type of action man does in order to save his life and survive the surrounding dangers (Carroll, 2012, p.24). Beckett's Waiting for Godot lacks any coherent action. Two tramps are staged in a bare scene, with only one barren tree, struggling over their boots and other trifling materials. They cannot be sure whether they have already met Godot, or even they know him or not. The two are trying to kill the time, so that with the passage of time a possibly better future comes. It appears that killing time, talking nonsense and waiting are the only actions these two are capable of doing. Waiting as an action for survival and the passage of time appear to be their only business, and the only thing they are capable of doing. Survival is only possible if they wait for Godot. The only action is waiting, as it could be read in the following lines:

Vladimir: Well? What do we do?

Estragon: Don't let's do anything. It's safer. 
Vladimir: Let's wait and see what he says.

Estragon: Who?

Vladimir: Godot. (Beckett 7)

Waiting as their only act is not a proper action for survival. They have no idea of Godot's identity, making their waiting a purposeless act. When Pozzo comes along with Lucky, they take him for Godot; as Pozzo says: "You took me for Godot", and Estragon admits "Nothing of the kind, we hardly know him" (9-10). They do not know whom they are waiting for. In fact, it appears that, somewhat like the activities they get amused by when visiting Pozzo and Lucky, waiting is just what would make them live on their repetitious life. Paradoxically enough, waiting is supposed to give their life a meaning, while it is devoid of meaning in itself. In the very first act of the play the audience witnesses the struggle of Estragon for taking off the boat, uttering the first line "nothing to be done". After a senseless discussion about a Biblical story, the two come to the only concerned action, that of waiting:

Estragon: Charming spot. (He turns, advances to front, halts facing auditorium.) Inspiring prospects. (He turns to Vladimir.) Let's go.

Vladimir: We can't.

Estragon: Why not?

Vladimir: We're waiting for Godot.

Estragon: (despairingly). Ah! (Pause.) You're sure it was here?

Vladimir: What?

Estragon: That we were to wait.

Vladimir: He said by the tree. (They look at the tree.) Do you see any others?

(Beckett 5)

Waiting turns into their only shared activity, while it is no action. The four people on the stage are all confusingly attempting to search for a meaning in life. Waiting cannot be regarded as a positive dramatic action. Waiting for Godot to come cannot be viewed also as an act for survival, as it is an act bereft of meaning, signifying nothing. Nothing and non-action are repeatedly seen in their conversations as well as in the stage direction. Estragon complains "Nothing happens, nobody comes, nobody goes, it's awful!" The conversations end in the demand to take action while the stage directions invite the actors not to move: He does not move (Beckett 21)

Not only the tramps, but also Pozzo and Lucky are, entangled in the web of waiting. Lucky awaits his master's command in order to dance or even think. The inability to comprehend the commands of a master or the nature of their waiting once more proves the lack of agency and power in the characters to pursue their life goals and attempt to survive. As Bachakus (2002) agrees: "Their inaction is at once ambiguously imposed on them and a voluntary choosing. They are ahead-of themselves, but in a predicament in which they cannot know the nature of the goal for which they wait (fundamental in transparency)" (p.92).

The action often turns to cruelty and persecution: Pozzo torments Lucky, Estragon kicks Lucky to avenge himself, Vladimir strikes Pozzo to silence him. Sometimes the action can be almost gratuitous, as in the very fast exchange of three hats between Estragon and Vladimir in Act II, which is pure Laurel and Hardy (Fletcher, 1967, pp. 61-62). The trivial actions, such as struggling over the dance of Lucky or taking off their boots, would have no ultimate future. The action that would lead to survival, as defined by Carroll, would eventually lead to a conclusion. Such banalities are not meaningful enough to be regarded in one category with actions towards survival. It becomes clear that Vladimir, Estragon, Pozzo and Lucky are all demonstrating 
nothing, no such action, suggesting their attempt for survival. It is thus possible to agree with Barry (2007) that "Beckett's imaginative universe in general presents itself as a world where there are only patient ... where action itself is simply, as in the original Latin verb patior, to undergo experiences passively while waiting for the end" (Barry, p.117). Beckett's world is that of inaction, ennui and depression, where the only inhabitants are patient, in its true sense of the word, who are not doing anything significant to be relieved from the stagnant situation. The action, as Richard Schechner (1986) believes, is not "what these two characters are after but it is what they most want to avoid" (p.16). Walter D. Asmus (1986) in his article, "Beckett Directs Godot", reminds us that "waiting is the play's action" (p.335).

\section{Social Efforts (Helping non-kin and Making Friends)}

The second category of human nature attributes presented by Carroll in Reading Human Nature concerns the social and cultural elements that constitute constructive effort by human beings in order to gain a desirable social life. Helping non-kin and making friends are mentioned as the two sub-categories of these efforts. Beckett's Waiting for Godot shows the absence of these social interactions in the catastrophic post war era. Social interactions are totally out of place in this play. Every little chat would end up in a quarrel and a guest's presence can never be tolerated. Pozzo and Lucky apparently has had a friendly relationship which is turned into a master-slave one now. Pozzo says that Lucky "can no longer endure my presence. I am perhaps not particularly human, but who cares?" (Beckett 13). Besides, there is no evident act towards building a friendly relationship in the whole play.

We witness neither physical nor mental action in Beckett's Waiting for Godot which is a good example of inaction and idle talk. The tramps insist on passive waiting which the characteristics of the post-war era when, as Estragon says, "billions of people are waiting" and will to action is paralyzed. The images of boots and hats make the situation clear. Tight boots reminds us of Dickens' Little Dorrit in which tight clothes and boots suggest prison and chains. Boots that are too tight, like those of Estragon, are obstacles in the way of physical action and hats that stand for thinking are no longer needed because both body and mind are paralyzed. It is the time when any action seems harmful. When Pozzo and Lucky return in the second act, they are cruelly deformed by the action of time. Therefore, any action seems disastrous or useless, but waiting is also useless because the arrival of Godot is an illusion.

Being unable to act is not limited to the physical sense in Waiting for Godot. Making friends, or "helping non-kin" in Carroll's phrase, makes a universal human nature attribute (2012, p.45). stages pairs of characters in the play, namely, Vladimir and Estragon, as well as Pozzo and Lucky: pairs of characters that are unhappy together but are complementary. Their relationship is also a male-dominant one in which Pozzo seeks and maintains the status of the master. Though, as the play continues, he proves to be the master of nonsense. Lucky symbolizes the lost intellect in humanity, which is now enslaved and doomed to a chaotic stance, ruled by someone else: "Lucky deserves his name because he has a master who, however cruel, organizes his life for him . .. of his original dancing nothing is left but a slouch and totter, and his thinking has deteriorated into the endless repetition of meaningless word reminiscent of the 'word-salad' of schizorphrenics" (Metman, 1965, p.122).

Pozzo is a post-war tyrant who owns the mind of his servile servant and has dehumanized him. Lucky's role is that of a dehumanized thinker or artist who has been subjected to terrible 
servility. Therefore, there is no hope for the post-war generation. The boy who comes to tell the tramps that Godot is not coming belongs to the present time, but his brother who "minds to sleep" and is beaten by Godot and comes the next day to tell the same news, belongs to the next generation; that is, the tramps are getting older and although their waiting has been useless, they do not get involved in the action of an ignoble society.

The nature of Vladimir and Estragon needs more clarification. They are similar and at the same time, differ in certain aspects. Estragon is more oriented towards his feelings. Simplemindedness in hope and bitter despair are the natural outcome of his strong emotions. He is rebellious and at times quite dependent as a boy on Vladimir. Vladimir; however, is more dominant and power seeking: he is an older friend, whose long speech in the second act makes him different from Estragon as being more in favor of thinking. Meanwhile, the slight points of differences between the two couples lead them nowhere, not to a productive end, but toward struggle and time-wasting. They are doomed to the killing of time. They do not know why they live together, but they do know that they cannot live without each another:

Vladimir: Let them remain private. You know I can't bear that.

Estragon: (coldly.) There are times when I wonder if it wouldn't be better for us to part.

Vladimir: You wouldn't go far.

Estragon: That would be too bad, really too bad. (Pause.) Wouldn't it, Didi, be really too bad? (Pause.) When you think of the beauty of the way. (Pause.) And the goodness of the wayfarers. (Pause. Wheedling.) Wouldn't it, Didi? (Beckett 5-6)

The characters in this play fail to show the proper social interactions. Friendship is absent in the play and the relationship between Vladimir and Estragon is more of a sick dependence upon one another rather than a friendly one. Pozzo and Lucky are more master-slave than friends. The tramps, moreover, are not able to interact properly with Pozzo and Lucky as well, leading all relationships to a failure.

\section{Mating Efforts}

The desire to have children and to nurture a successful generation to continue life has deep roots in the human "life-history". In fact, it is the demand of reproduction that would eventually shape the long term relationship between a man and a woman, so as to grow up the next generation. Literature as the production of an adapted mind is the true representation of human wishes, dreams and desires. In other words, human life history is truly mirrored in literature. Mating efforts, i.e. the desire to have a long term relationship and nurturing children is another motive that Carroll delineates as the action directed toward survival, by the way of reproduction. . Every species has its own form of these emotions which would eventually shape the "life history" of that species. In case of human life history, there is a reproductive cycle which centers on parents, children, and the social group. Eventually if there is successful parental care, children are produced who are capable of entering adult pair band, when grown, and becoming the functioning members of the community. (Carroll 2011, p.14)

Waiting for Godot has no female character in it. There is no direct reference to the theme of any romantic relationship, nor any sign of the hope for reproduction. In the meantime, there are two symbols by means of which Beckett has artistically denoted the universal human nature attribute of reproduction in this play, which is evidently the result of a mind adapted to the harsh, 
modern wasteland. The tree is totally barren in the first act. Although in the second act there is apparently a single leaf hanging from the tree, evidently it is too powerless to suggest fertility. There is no female character in the play which could signify lack of reproduction. What we witness in this play, according to Gunther (1985) is "no longer real action; for it has no objective (p.146). No action towards reproduction is observable.

Suicidal intentions take the place of giving birth as Beckett artistically juxtaposes the sexual imagery with that of hanging. Birth and death, and what comes in between, are not considered so much as actions as the processes that the subject undergoes, and sometimes, in Beckett's destabilizing world, one finds it difficult to distinguish them from each other. The following extract from the play designates the desire for committing suicide, which is taking the place of birth and action.

Vladimir: It's for the kidneys. (Silence. Estragon looks attentively at the tree.) What do we do now?

Estragon: Wait.

Vladimir: Yes, but while waiting.

Estragon: What about hanging ourselves?

Vladimir: Hmm. It'd give us an erection.

Estragon: (highly excited). An erection!

Vladimir: With all that follows. Where it falls mandrakes grow. That's why they shriek when you pull them up. Did you not know that?

Estragon: Let's hang ourselves immediately! (Beckett 6)

The nature of relationship between the characters would make it senseless to expect anything productive to come out of it. The couple's dependence on each other is so overwhelmingly seen in the play that it appears that waiting and their boring life are what they are going to leave for the next generation. No child or family is present in the play. In the second act, Estragon decides to leave the boots: "(turning to look at the boots). I'm leaving them there. (Pause.) Another will come, just as . . a as . . . as me, but with smaller feet, and they'll make him happy." But Vladimir's response is harshly realistic as he reminds us of their goalless life again and again, making the wish for some "smaller feet" to vanish away. He says: "We've nothing more to do here." In other words, it is possible to agree that in the case of Pozzo and Lucky "Pozzo illustrates the futility of all human tyranny, for he has a morbid need for attention and for the consideration of others, and he takes pleasure in declaiming before an audience of tramps and revealing to them his mawkish attitude to Lucky" (Fletcher, 1967, p.5o).

\section{Constructive Efforts}

Constructive efforts are the universally common characteristics among all human beings that are aimed at constructing man's life. Human beings have universally been concerned with the search for power, wealth and better social stance. These sets of behavioral attributes, as defined by Carroll in Reading Human Nature, delineate the universal human nature. Creating something new is a sign of man's struggle to survive according to Carroll (2011, p.17). Building and creating helps human beings progress and increase their chances of propagating genes and survive. Through such acts, man is able to enhance the quality of his life. Putting emphasis on the theatrical quality of the play, McDonald (2006) asserts that Beckett's Waiting for Godot is interwoven with the idea of a play within a play. The play bears essential meta-theatrical elements, but the fact that these 
inactive, passive tramps certainly and consciously interact with one another needs more explanation. McDonald brings evidence from Act II, when the pair actually play trivial games. He states that both Vladimir and Estragon are indulged in "many self-conscious performances, the idea that the dialogue between Vladimir and Estragon is a kind of 'game' (p.91).

The point is that such performativity is pregnant with no result. Nothing new is created and all things are repeated in a cycle all over again. The second act resembles the first one in most details, and no sign of change is ever present, neither in the physical attributes of the characters nor in the progress of the plot. There is no plot to move the characters forward. Concerning Vladimir and Estragon, Metman (1965) states that: "Their incapacity to live or to end life, the opening and concluding theme of the play, is intimately linked with their love of helplessness and of wish dreams which they make no attempt to realize" (p.121). They wish they could act, but the impotency to act prevents them to take any action and create anything new. They have to wait again and nothing changes. Thus, such theatricality bears no essential change in their static situation. Nothing new is built or invented and no game is played to ensure the other human nature motif defined by Carroll. The characters in this play resemble the post-war man who is not entangled in the attempt to fulfill the human universal motif.

Search for power, wealth and education are other categories of actions that are defined as "constructive efforts" by Carroll. Similar to the motif of building something new, power and wealth seeking is a universal human nature attribute. The main characters in Waiting for Godot are clearly tramps that only do not have any money, but are not even concerned with financial materials as such. It appears that wealth and power have lost their meanings in their world and they are concerned only with waiting for Godot to come by and fertilize their barren land. Whether he comes or not, as a result of inaction, the element of destruction is already deep enough in their present situation. Beckett belongs to the twentieth century with all its features, pessimistic or optimistic, which are reasons enough to consider lack of any enthusiasm for wealth or, in a broader term, for power in the characters. In a world devoid of meaning and enthusiasm for life, seeking power, wealth and education appears as a senseless act. All the characters in Beckett's Waiting for Godot are bereft of wealth and significant social status and they have no intention to pursue these goals at all. Nothing to be build, no wealth and education to seek, the characters in this play suffer lack of potency to accomplish life's goals.

\section{Conclusion}

The twentieth-century man in Beckett is more an anti-hero than a hero. He is bereft of human attributes and suffers as a result. His ennui, depression, inaction, inertia, and passivity are the direct or indirect consequences of the surrounding conditions. Modern man is staged as captivated in the extreme web of solidarity. The surrounding is so much devastating that no hope exists and nothing is pursued. Sobosan (1976) believes that "our age is that of . . anti-hero, the man so completely incapable of significant action that any identification with him means at least a partial abandonment of that ego ideal toward which we all strive, if only in our dreams" (p.183). Beckett's anti-heroes belong to the same age.

Beckett was assuredly under the direct and indirect influence of important events of the twentieth century as they shaped the society in which he lived. The philosophical arena was filled with pessimistic hollowness followed by some literary movements, such as existentialism or the Literature of the Absurd, which was dominant in Europe during the forties and fifties, and to which Beckett is very often allied. Nietzche's famous utterance of the death of God brought with 
it a horrible sense of despair and loneliness to the modern man. It is such a spirit which shapes the barren landscape for the tramps, with just one tree, and a road leading nowhere. When Pozzo, as a post-war man, cries for help, Vladimir talks about "this immense confusion" and Estragon admits that "We are all born mad." This is a sound criticism of the post-war era when people are wandering the Wasteland and all the attributes of human nature as defined by Darwinists are dead or paralyzed, when people are "dead men in life" according to D.H. Lawrence and Godot has nothing to do with what W.H. Auden calls "the Age of Anxiety" when inaction prevails.

The attributes that constitute the core features of universal human nature, as defined by Joseph Carroll in Reading Human Nature, require a certain amount of agency to lead to action. The constructive efforts, which are accordingly defined as the characteristic features of protagonists in a literary work, are absent in Beckett's Waiting for Godot. Vladimir and Estragon do not show any single attempt towards survival and the only action they can think of is suicide. The paradox is that even committing suicide is an action which is doomed to failure in the hands of these two tramps. The mating efforts are even more clearly not present in the play. The female characters are not only absent but are not even referred to and the only sign of reproduction is a barren tree. There is no single reference to the issues of romance and reproduction in the whole play. It is clear that in Waiting for Godot, no action is done ever to have the intention of survival; in fact no action is done by the tramps. The absence of any female characters signifies a failure in the actions aimed at reproduction, and the two tramps are apparently bereft of wealth and power.

\section{References}

Asmus, Walter D. (1986). Rehearsal Notes for the German Premier of Samuel Beckett's That Time and Footfall's". In S.E. Gontarski Editor, On Beckett: Essays and Criticisms (335-49). New York: Grove Press.

Bachakus, Gary. (2002). The Hidden Realities of the Everyday Life-World in Beckett's Waiting for Godot and Genet's The Balcony. A.-T Tymieniecka. Analecta Husserliana, 75, 81-115.

Barry, Elizabeth. (2007). One's Own Company: Agency, Identity and the Middle Voice in the Work of Samuel Beckett. Journal of Modern Literature, 31 (2), 115-132.

Beckett, Samuel. (1954). Waiting for Godot. New York: Grove.

Carrabino, Victor. (1985). On the Shores of Nothingness: Beckett's Embers. Analecta Husserliana, 10, 57-66.

Carroll, Joseph, et al. (2012). Graphing Jane Austen: The Evolutionary Basis of Literary Meaning. London: Palgrave.

Carroll, Joseph. (2011). Reading Human Nature: Literary Darwinism in Theory and Practice. London: SUNY Press.

Carroll, Joseph. (2004). Literary Darwinism: Evolution, Human Nature and Literature. London: Routledge.

Cohn, R. Ed. (1967). Casebook on Waiting for Godot. New York: Grove Press Inc.

Fletcher, John. (1967). Samuel Beckett's Art. Chatto \&Windus: LondonS.

Gunther, Andres. (1085). Being Without Time, On Beckett's Waiting for Godot. Martin Esslin Editor, Samuel Beckett: A Collection of Critical Essays. (108-116) New York: Prentice-Hall International.

Gordon, Lois. (2002) Reading Godot. New Haven and London: Yale University Press.

Metman, Ev. (1965). Reflections on Samuel Beckett's Plays." In Martin Esslin Editor, Samuel Beckett: A Collection of Critical Essays. (117-136). New York: Prentice Hall, Inc.

McDonald, Ronan. (2006). The Cambridge Introduction to Samuel Beckett. Cambridge: Cambridge University Press. 